\title{
A MUSEUM AS A RESEARCH AND SCIENTIFIC CENTRE FOR ARCHAEOLOGICAL STUDIES (UKRAINIAN SOCIALISTIC SOVIET REPUBLIC MUSEUMS EXPERIENCE IN THE 1920s - FIRST HALF OF 1930s)
}

KEYwORDs: museum archaeology; field archaeological research; archaeological investigations methods; training of museum archaeological staff; UkrSSR; the 1920s first half 1930 s

SŁowa KLuczowe: archeologia muzealna; badania archeologiczne; metody badań archeologicznych; szkolenia pracowników archeologicznych; Ukraińska Socjalistyczna Republika Radziecka; 1920 - pierwsza połowa lat trzydziestych XX w

Archaeology of UkrSSR in the 1920s - early 1930s had been developing due to research activities of scientists, majority of whom represented research intellectual community of pre-revolutionary Russian empire. They worked in different state, regional and local institutions. Furthermore, museum fellows conducted and took part in the vast majority of archaeological research, while academic research centers aimed to coordinate and organize the research. The 1920s were the peak period of local lore studies, which involved complex research of archaeological and ethnographical sites, history and nature of the region. Museums started to be the centers of local lore studies, or so called "small academies" as they were named by Mykola Sharleman. They organized collecting, research, systematizing, introducing for scientific use, popularization and protection of archaeological and historical sites. New generation of Ukrainian archaeologists was formed in all-Ukrainian and local museums. Later, some of them joined academic institutions such as Section of Material Culture History, Institute of Material Culture History, UkrSSR Institute of Archaeology.

Historian, linguist and head of museum and library section of UkrSSR scientific organizations administration in the 1920s Vasyl Dubrovskyi characterized Ukrainian museum. He pointed out that: 
[...] a contemporary museum consists of three mutually-determined elements:

1) collections of culture artefacts or nature objects, which are chosen and exhibited on scientific background (totally or partially); 2) employees, qualified in one or another field; 3) their work, including research and outreach activities [...]. Research knowledge, and mediums of this knowledge, is the base for any real museum work. Museum is a research institution [...] and the integrity of educational use of museums is only one among other applied results of the major research work in the museum [...]. Following the term [museum] we interpret it as an educational institution which collects, systematizes, preserves, publishes and exhibits material culture and nature objects for wide popularization [...]. The first distinguishing feature of museum work is culture and nature objects collecting and its systematizing on scientific principles (Dubrovskyj 2007).

UkrSSR museums diverse areas of activities included scientific and research work, scientific collections management, exposition, cultural and educational work. All these activities were to involve working out of archaeological materials, conducting field, laboratory and in-office research, developing courses of lectures, guided-tours programs, etc. During the interwar period, main purpose of UkrSSR museums in the archaeology field included: discovery, registration, primary examination, investigation of archaeological sites from different areas, primary accumulation of archaeological material.

Archaeological collections acquisition was realized through expeditionary activities - conducting archaeological fieldwork in different forms. As of 1919-1934, three sorts of archaeological investigations can be distinguished: reconnaissance, surveying, and excavations.

The author of this article collected information on 2070 archaeological sites of a wide chronological range - from the Paleolithic to the Late Middle Ages and Modern time. All of these sites were investigated by UkrSSR museum fellows during 1919-1934. 1772 sites were investigated through survey; excavations were conducted on 412 sites (114 locations were investigated by both survey and excavations).

The principal form of archaeological site study was survey investigation of different types: reconnaissance, excursions, registration, visual examination, fixation, measurement, tours to the places of accidental finds, illegal excavations and places of triangulation pillar installation, supervision during building activities etc. Predominance of surveying over excavations during this time period was likely due to lack of material and financial support and shortage of time for conducting stationary systematic excavations. Additionally, not all museum workers were qualified and experienced enough to get an official permit to conduct excavations. 
Speaking of excavations significance, its necessity and expediency, Mykola Sibiliov pointed out:

Excavations are the last word, the final accord of fieldwork. Excavations can determine the age of a site, and to which culture found artifacts belong. But nowadays, while the majority of local museums seriously lack assignations for investigations, the excavations cannot determine the boundaries of the culture extension, and only spontaneously through excavations one can find out a new unknown culture in the area [...] excavations shouldn't be conducted while there are no qualified archaeologists in the majority of local museums; every excavation of a defended settlement "horodyŝe", non-defended settlement "selyŝe", burial site, or a temporary settlement ("stoianka") is a way to destroy the heritage site (Sibilov1936a: 33).

Archaeological surveys, according to Mykola Sibiliov, could have been conducted by "provincial museum fellows" aiming to discover a great number of chronologically different sites, to determine distribution limits of cultures; surveying by trenching opened up a possibility to estimate the age of a site and, what is especially important for museums, surveying gave serious amount of different archaeological material for further exposing (Sibilov 1936a: 33).

Among the surveys, led by UkrSSR museum workers during the 1920s - first half of 1930s, dominated so called geographical, route excursions/surveys in river basins. Poltava Museum conducted surveys over the banks of Berestovenka, Orchyk, Psel rivers. Surveys by Volyn Research and Investigation Museum covered riversides of Guiva, Zhereva, Perga, Sluch, Teteriv, Tiuhterivka, Ubort, Uzh etc. Petro Pinevych, Mariupol Museum employee, conducted excursions/ surveys along riverside of Kalmius. Jakiv Morachevskyi surveyed riverbanks of Keleven, Seim, Ivot rivers, etc.

On a regular basis, museum employees monitored building activities in various localities. Thus, in 1924 Konotop Museum fellows accomplished "materials collecting at the building works" at Soborna square of the town (SA IA NASU: f. VUAK, f. 46/11). All-Ukrainian Taras Ševčenko History Museum fellows looked after the building works in Kyiv in 1926 (SA IA NASU: f. VUAK, f. 86/2r). Jakiv Morachevskyi investigated cultural layers of Glukhiv in 1926-1927, while water piping system was installed (CDAVO: f. 166, inv. 6, f. 172, s. 227-229). Todos Movchanivskyi surveyed earthworks in Pohrebyshche village (Vinnycia region) in 1928 (SA IA NASU: f. VUAK, f. 309/6). Mykhailo Semenchyk, Romny Museum fellow, visited school building site at Vedmezhe village (Romny district, Sumy region) (CDAVO: f. 166, inv. 6, f. 9425). A museum fellow F. Ivanov, while observing water-pipe construction, discovered Paleolithic location in Oleksandria park at Bila Tserkva town (SA IA NASU: 
f. VUAK, f. 202/1) (fig. 1). Ipolit Zborovsky, head of Tulčyn Museum, surveyed and conducted rescue excavations in 1929, while stone-block pavement was done over the street in Budy village (Troctanec district, Vinnycia region) (SA IA NASU: f. 3, f. 90) (fig. 2).

Archaeologists - museum fellows worked on a question of fieldwork archaeological investigations methods, on artifacts processing, and on museumification (restoration, conservation, etc.). Methodical studies on surveying and excavations technics were published in the second half of the 1920s. Research papers by museum fellows Sergij Gamčenko, Myhajlo Rudynskyj, Mykola Sibilov, Oleksandr Fedorovskyj assured further improvements in field archaeology methods. Some studies can be considered as methodical manuals on field archaeology. These included: Instruction and programs for surveying and registration of archaeological sites (Instrukcii ta prohramy dla rozvidok I rejestracii pam’jatok archeologičnyh) by Oleksandr Fedorovskyj (1927), Archaeological primary sources, ways of its registration and protection (Archeologični peršodžereta, sposoby ïh rejestracii ta zasoby ohorony) by Serhii Gamchenko (1925), Searches over sand riverbanks (Rozšuky po piskovyh nadberežžah ričok) by Myhajlo Rudynskyj (1925), How I conduct archaeological surveys (Kak ja provožu archeologičeskije razvedki), Archaeological surveying at new building sites (Archeologičeskije razvedki v rajone novostrojek), and Archaeological investigations by museums of local lore (Archeologičeskije issledovanija krajevedčeskih muzejev) by Mykola Sibiliov (1928; 1935; 1936a).

A number of museums worked out questions of archaeological technology. Kamianets-Podilsky Museum collaborated with Leningrad Institute of Archaeological Technology regarding to the case of Trypillia culture sites in Podillia (CDAVO: f. 166, inv. 6, f. 6115, p. 9). Institute of Archaeological Technology fellows kept in research contact with Mykolaiv History and Archaeology Museum (SA IA NASU: f. VUAK, f. 202/6, p. 4). Set of Trypillia pottery fragments with textile imprints from Tulčyn museum excavations at Stina village (Tomašpilskyj district) was sent to be investigated by Vasyl Favoskyj - chief of Kyiv Cabinet (Institute) for Scientific and Forensic Enquiry (SA IA NASU: f. 3, f. 44) (fig. 3). Andrij Dragojev, Odessa History and Archaeology Museum librarian, tutored research lessons for young museum staff in the fields of archaeological technology (ceramics) and museology, led chemical and technological observations of "ceramic materials resistance to atmosphere influences and ceramics production technology in ancient times" 
(CDAVO: f. 166, inv. 5, f. 750, p. 2). Myhajlo Boltenko studied questions of wine production technology during Antique times (CDAVO: f. 166, inv. 6, f. 172, p. 33).

UkrSSR museums carried out restoration works. For example, during 1926/1927 Odessa History and Archaeology Museum fellows used various restoration methods: rinsing of ceramics "which suffered from salts crystallization", in sweet water, "re-gluing of pottery and glass vases", etc. (Vidcyt... 1927). Besides the routine work with archaeological materials, received during expedition activities, this museum staff also worked on the questions of history of Northern Black Sea region archaeology, were involved in creating catalogues of funds collection of the institution, etc. (CDAVO: f. 166, inv. 3, f. 427).

All-Ukrainian Archaeological Committee (VUAK) and republican museums' methodical and qualification level was higher than the one of "provincial museum fellows". Due to this, during the excavations initiated by a museum institution, existed practice of inviting "capital" institutions fellows. For example, archaeological investigations of such a character were led on the territory of "Azovstal" new building sites. These investigations were initiated by appeal of I. Kovalenko, director of Mariupol Museum of Local Lore, to the VUAK in February, 1930, and were conducted during 1930-1933 under Mykola Makarenko's guidance, with the participation of museum fellows I. Kovalenko, N. Kovalenko and M. Jegorova (SA IA NASU: f. VUAK, f. 486) (fig. 4). Sergij Gamčenko, titular member of VUAK, administered and provided a consultative role for Tulčyn and Šepetivka Regional Local Lore museums. His laboratory assistants Olena Lagodovska and Mykhailo Makarevych also took part in excavations over the Tulčyn district etc. (SA IA NASU: f. VUAK, f. 256).

Systematization of archaeological fieldwork in regions was realized, among all other factors, through creating archaeological maps. Odessa and Herson museums worked on creating Odessa region (hubernija) map. Archaeological sites mapping for the region was considered to be a special scientific and research direction, which aimed to create:

[...] a powerful basis for further applied archaeological work in Northern Black Sea region through accurate recording and systematization of all the previous fellows' successes in the branch of archaeological regional studies (CDAVO: f. 166, inv. 2, f. 454, p. 614).

In the early 1920s Maks Morgulis, Odessa History and Archaeology Museum fellow, worked on creating Odessa region archaeological map "according to the 
principles, set by Volodymyr Antonovyč and Dmytro Bagalij” (CDAVO: f. 166, inv. 2, f. 454, p. 614). Research investigation of Harkiv Archaeology Museum collections was complemented by archaeological mapping (CDAVO: f. 166, inv. 2, f. 469, p. 70-72). Archaeological investigation of Volyn region, led by museum fellows, went along with "supplementing archaeological maps for the region" (CDAVO: f. 166, inv. 3, f. 1166, p. 22). One of the main assignments for Katerynoslav History and Archaeology Museum was to develop and compose archaeological maps of the region. Several archaeological maps were composed in Katerynoslav and Novomoskovsk in 1924 (CDAVO: f. 166, inv. 4, f. 267, p. 6). Romny Museum started working on archaeological mapping in 19251926; topography plans were produced for 7 defended settlements, one burial site, and about 70 burial mounds were put on a map (CDAVO: f. 166, inv. 6, f. 8199, p. 14). The "operational plan" of Zinoviev Museum for 1928-1929 included the assignment "to create the map of archaeological investigations over Zinoviivŝyna" (CDAVO: f. 166, inv. 6, f. 1861, p. 60). "Archaeological map of the district" was kept in Ohtyrka Local Lands Museum collection up to $1^{\text {st }}$ January of 1929; defended settlements, temporary settlements, and stone anthropomorphic figures' locations were mapped; it was planned to be used on purpose of development of institution archaeological department (SA IA NASU: f. VUAK, f. 275, p. 6).

UkrSSR Museum activities in the field of archaeological mapping were seriously supported and encouraged by academy structures. In particular, Commission for Creating the Archaeological Map of Ukraine in 1919-1920 declared principles of adjusting organizational connections with scientific centers and separate researchers, usage of inventory books, catalogues, and museum institutions collections (SA IA NASU: f. VUAK, f. 50). But real changes in museum activities coordination took place only in the early 1930s. Thus, VUAK initiated a proposition to other museums in 1931; it aimed "to take part in creating archaeological map for the recent 15 years period of activities". To accomplish that, museums received special cards, which were to be filled with further information on archaeological site: location name (district, village, area "urochyshche", distance to the village); investigations character (reconnaissance/surveying, excavations), researcher's last name, year; site characterization; culture, age, chronology, borders; other information. VUAK also suggested that museum staff, when filling in the cards, first of all tried to "use unpublished museum materials and those known only inside the museum" (SA IA NASU: f. VUAK, f. 407, p. 4). Jurij Vynogradskyj, a head of Sosnytsia Museum, Oleksandr Tahtaj, newly a assigned director of Herson Museum, and Volodymyr Kočubej, a head 
of Šepetivka Museum, agreed to take part in creating the map. But, due to lack of time, filling in the cards was not properly accomplished. Specifically, Oleksandr Tahtaj's work on filling in the cards for archaeological mapping was delayed due to the need of receiving the Herson Museum from the previous collective of fellows. Late in 1931, VUAK archaeology department approved creating the map of Donbass archaeological sites and planned to "concentrate attention for 1932 on collecting data for the mentioned theme" (SA IA NASU: f. VUAK, f. 407, p. 30). VUAK called out the regional museums and offered to take part in this assignment. Luhansk and Mariupol Museums announced their readiness to start working on archaeological mapping for Donbass (to conduct necessary reconnaissance in 1932, to compose cards with information on archaeological sites). Thus, on $5^{\text {th }}$ May 1932, Luhansk Museum sent 50 samples of filled in cards to VUAK for preparing the archaeological map (SA IA NASU: f. VUAK, f. 407).

During the 1920s - early 1930s research academic institutions, skilled archaeologists, archaeological museums, archaeological departments and regional museum collections, archaeological periodicals and monographs composed tightly connected elements of archaeology organizational structure. Museum fellows' publications reflected work of research institutions and representatives of research archaeological community. Archaeological fieldwork by UkrSSR museum institutions were represented within 150 publications. During the 1920s - mid 1950s articles and monographs were published, in which information on 940 archaeological sites investigated by museum fellows was given (47\% of total number of locations explored by museum fellows). Periodicals and museum institutions proceedings were an important mechanism of introducing the results of archaeological fieldwork for scientific use during the 1920s - in early 1930s. Odessa State History and Archaeology Museum activities in 1926-1928 were presented in "Reports (Vidčyty)" (Vidčyt... 1927; 1929) (fig. 5). In 1928 museum published „Catalogue of exhibition on local archaeology achievements during 10 years (1917-1927), and artworks portraying local lore" (Kataloh... 1928). Herson History and Archaeology Museum, continuing pre-revolutionary traditions, published "Litopys (The Chronicle)", two volumes of which portrayed events of institution's research and scientific life in 1917-1928 (Litopys... 1927; 1929) (fig. 6). In 1928-1929 proceedings were published in further institutions: Volyn Research and Science Museum, Dnipropetrovsk Local History and Archaeology Museum, Volodymyr Korolenko Poltava State Museum (Zbirnyk... 1928a; 1928b; 1929). They included papers by Ivan Levytskyj, Myhajlo Rudynskyj, 
Pavlo Matvijevskyj, Oleksandr Tahtaj and others. Collected papers of Izium Museum - "Antiquities of Iziumŝyna (Starovynnosti Iziumŝyny)" - were published four times and were dedicated to large-scale surveying by Mykola Sibilov (1926a; 1926b; 1930; Starovynnosti... 1928). With the assistance of Izium Museum, regional paper collection „Iziumŝyna” was published (Iziumŝyna... 1930). Here among the papers, one can find an investigation by Mykola Sibilov, dedicated to "Careborysiv zaslonna smuha", as well as the paper by Oleksandr Zaharov about a Scythian-Sarmatian burial, found in 1929 not far from Balakleja town. With the assistance of Mykolaiv History and Archaeology Museum, regional paper collection Nikolajevŝyna was published (Nikolajevŝyna.. 1926), and later - Short Report on Mykolaiv History and Archaeology Museum Acivities in 1927 (Korotke zvidomlennia... 1928). Prehistorical Antiquities in the basin of Donets River by Oleksandr Fedorovskyj, a director of Harkiv Archaeological Museum, was published within the pages of "Lisičansk Museum Bulletin" (Fedorovskyj A. 1921) and was based on the results of previous regional archaeological investigations. Considerable part of publications, dedicated to results of UkrSSR museums research and scientific work, was published in academic issues of Soviet Ukraine and Russia, printed organs of All-Ukrainian Local History Committee, Scientific Institutions Administration of People's Commissariat of Education in UkrSSR, higher education institutions editions, as well as in popular science journals and periodicals of the 1920s - 1930s ("Vsesvit", "Znannia", "Radianska Shkola" etc.).

Among those publications, dominate reports on archaeological fieldwork conducted with participation of museum fellows (72\%) - including surveying/ reconnaissance, excavations, tours to the places of accidental finds etc. Specifically research publications based on materials, received within the excavations, formed less than a quarter of total publications amount (21\%). A small group of publications was represented with book guides, catalogues, regional guidescollections, general works on museum history, scientific popular issues which contained information about the materials received as a result archaeological fieldwork and conducted by museum institutions (7\%).

Fieldwork material collected during museum archaeological investigations, according to "vidkryti lyst" (a permit for excavations) regulations, was to be transferred to the funds collection of an institution, and later it was widely used in expositional, cultural, and educational work.

Archaeological materials of Odessa State History and Archaeology Museum in 1926 were represented by departments: department of prehistory 
(Neolithic, Eneolithic - Trypillia culture, materials from Usatove, and Slobidka-Romanivka (New Slobidka) villages), departments of Bronze Age, of nomadic culture during the historical era - stone anthropomorphic stele); Classical Oriental cultures (Egypt); Northern Black Sea region Hellenistic and Greek-Romanian colonization (the main part of museum collections) - Tanais, Olbia, Chersonessos, Pheodosia, Pantikapei, Tiras; Middle Ages cultures; Zaporižžia antiquities and so called 'Novorossia'; arms department; numismatic cabinet (CDAVO: f. 166, inv. 5, f. 262, p. 165-167). Mykolaiv History and Culture Museum exhibited museum objects by departments: the Olbian, "Ancient Mykolaiv", navy, Ukrainian, numismatic (CDAVO: f. 166, inv. 5, f. 262, p. 169). Exhibits in Harkiv Archaeology Museum were placed in the departments of Stone Age, Eneolithic and Neolithic Ages, Scythians and Sarmatians, Goths, Alans, late nomadic people, Slavs and Tartars (CDAVO: f. 166, inv. 5, f. 262, s. 112). Herson Archaeological Museum formed its archaeological exposition by sub-departments of: prehistory, Antique and Scythian-Sarmatian period, Great Migration period, Lithuanian-Polish-Tartarian-Turkish-Zaporižžia-Ukrainian, Russian colonialism period (CDAVO: f. 166, inv. 6, f. 172, p. 96-98). Fieldwork investigation results of museum institutions were represented in history and archaeology, and archaeological departments of: Dzeržynskyj Social-historical Museum, Bila Cerkva, Vinnycia, Verhniačka, Vovčansk, Gluhiv, Dnipropetrovsk, Zvenyhorod, Zynoviiev, Kamianets-Podilskyj, All-Ukrainian Historical, Konotop, Krasnopilka, Kupiansk, Lohvytsia, Lubny, Mariupol, Myrgorod, Nikopol, Novhorod-Siverskyj, Olešky, Oster, Romny, Sokyrenci, Sosnycia, Sumy, Horol, Čerkasy and Černihiv Museums. The rest of museums exhibited archaeological materials within the departments of history and culture, society and history, "local region society", "everyday life and ideology", history of culture etc.

Practice of expositional charts constructing (sewing on charts) was popular in the 1920s. Such charts had been prepared either in the field, or during scientific and technical artifacts processing inside the museum. Charts with sewed-on material were used during creating the department expositions, charts photos were attached to scientific reports and publications. There is evidence (mostly photographic) of the expositional charts existence with the materials of museum expeditions in the 1920s - early 1930s from Romny, Lubny, Ohtyrka, NovhorodSiverskyj, Odesa, Černihiv Museums (fig. 7; fig. 8). Flint artifacts were also exhibited on glass plates (made of so called "Bem" glass), with black paper put underneath the glass surface (if the objects were white or grey), or with white 
paper (if flint was black, grey, or dark colored), flint tools were assembled to glass with wax mixed with gallipot or gelatin (Sibilov1936b: 15).

Speaking of system for archaeological staff exhibiting, Mykola Sibilov pointed out that each theme should have the central exhibits, which lively highlight the main idea of museum fellows who created the exposition. For example, in the window dedicated to the early kinship community economics, central place must have been taken by exhibits group signed as "work equipment produce" - nucleuses of different stages of processing, hammer-stones and other tools. The central place within the museum items underwritten as "fishing" was supposed to be taken with a fishing harpoon; among the artifacts for hunting - arrowheads, among the stuff connected with leather working - scrapers, cutters, flint needles etc. A director of Izium Museum pointed out that:

[...] one should not overwhelm museum visitor with abundance of artifacts, one should better show only the essentials and most typical things, but in the way which would allow the visitor to see not only through the written messages, but to see through the physical objects what was the relative weight $[\ldots]$ of occupations in the economics of mentioned time (Sibilov 1936a: 35).

Myhajlo Rudynskyj (2002/2003) defined main directions of cultural and educational museum activities and noticed:

[...] being a help for school and political educational organizations as of popularizing and educating with its collections, the museum must reveal itself in a range of events, in which it plays the major role, - in lectures-exhibitions on current and special topics, in guided-tours organizing and conducting. An exhibition, a lecture, a guided-tour as the museum functions draw attention of wider population to its second serious aim - to serve scientific intentions and country investigation.

According to Excursionist's Adviser published in 1928, All-Ukrainian Taras Ševčenko History Museum conducted excursions on further topics: 1) prehistorical human life; 2) life of a human during Stone Age on the territory of Ukraine; 3) Scythians and Greek culture of Ukrainian South; 4) household and everyday life of Naddniprianshchyna Slavs in X-XIII cent.; 5) Cossack times in Ukraine (Masalova 2008: 140-141).

In April 1929 "Archaeological investigations in Ukraine during 1928, exhibition by materials of Uprnauka (Scientific Office)" was opened in Harkiv Archaeology Museum in the course of "three-months campaign for Ukrainian culture" (CDAVO: f. 166, inv. 6, f. 8919). Exhibition displayed excavation materials of Doneck settlement in the museum exposition hall, the artifacts were "nicely exhibited in special containers". The exposition demonstrated different aspects of human life in Doneck settlement - its household activities and natural 
environment. Anthropological and osteological materials were also exhibited. Production activities of Doneck settlement human population were represented by the remnants of molding workshop with chalk templates, numerous ceramic items (houseware, toys etc.), remnants of workshop for producing antler and bone items, as well as work equipment and household stuff made of bronze, antler, iron etc. The exposition also presented models of potter's wheels which were found during excavations. The display was added by numerous photos of materials and the course of fieldwork, drawings, plans, and watercolors (V. K. 1930) (fig. 9).

VUAK exhibitions for 1925 and 1926 were the important mechanism of "presenting to citizens the achievements in the field of archaeological investigations". The first summarizing VUAK exhibition opened on $27^{\text {th }}$ December 1925 and lasted till $1^{\text {st }}$ February 1926; it aroused interest of the public (Nestula 1997: 61). Archaeologists and museum fellows Sergij Gamčenko, Ivan Levytskyj, Fedir Kozubovskyj, Petro Smoličev took part in VUAK public sessions dedicated to the exhibition. Among the exhibits of the 1925 summarizing exhibition were materials which came from cooperative fieldworks of VUAK fellows and UkrSSR museums fellows: from Trypillia culture settlements in the neighborhood of Jevmynka village (contributed to Oster Museum after the exhibition), from Trypillia and Bilogrudivska culture settlements in the neighborhood of Tomašivka village and from Bilogrudivskyj burial site (Uman Museum), from non-synchronous locations in Veremia, Gorobiivka villages, from Boryspil town (Taras Ševčenko All-Ukrainian History Museum) etc. (SA IA NASU: f. VUAK, f. 60) (fig. 10).

Speaking of the 1927 exhibition, VUAK representatives, considering financial complications, decided:

[...] as far as the principle of further VUAK exhibitions is participation of all researchers in the field of archaeology and art history in UkrSSR, we should be restricted to exhibiting this year only the investigation results of VUAK members and researchers who led their investigation at the VUAK expense (Nestula 1997: 63).

The 1926 final VUAK exhibition opening took place in the Public VUAN (AllUkrainian Academy of Sciences) Library building. According to VUAK letter to the VUAN administration of $15^{\text {th }}$ January 1927, the final exhibition was to display archaeological materials coming from excavations by Sergij Gamčenko on the Trubeckije homestead, by Valerija Kozlovska in Kyiv region, Petro Kurinnyi excavations in Berdyčiv and Uman districts, Mykola Makarenko excavations in Olbia and Poltava region, Myhajlo Rudynskyj investigations of Podilla and Poltava region, Petro Smoličev's surveys and excavations materials in Černihiv and Čerkasy regions, and also Myhajlo Boltenko's materials from excavations 
in Usatove and Velykyj Kujalnyk villages area (SA IA NASU: f. VUAK, f. 85, p. 12). Popularization of museum archaeology achievements through exhibiting within academic institutions was still efficient during the early 1930s. To take part in VUAN anniversary exhibition in March 1931, archaeological department of Volyn Museum sent Serhii Gamchenko's and Olena Lagodovska's materials from 1925 excavations in "Čorna Dolyna" locality (pottery fragments, anthropological material, clay coating fragments etc.); fragments of ceramics, stone and bone tools from Sergij Gamčenko's and Mykola Šavlovyč's excavations in 1925 at "Dača Bileckogo" and "Kumany" localities; 6 charts with pottery fragments from Sergij Gamčenko's and Ivan Levytskyj's excavations in "Piddoke" locality (SA IA NASU: f. I, f. 456, p. 35-39).

Archaeological knowledge popularization and general public "arousal" of "affectionate and careful" attitude towards local heritage objects as countrywide common property was realized by museum fellows through giving popular educational lectures on archaeological subjects. Therewith, Pavlo Riabkov, a founder and head of Zinovievsk History and Archaeology Museum, conducted scientific archaeological guided tours from 1919. Tours were accompanied by visiting burial mounds excavations and giving lectures on regional studies and world history studies (CDAVO: f. 166, inv. 4, f. 113, p. 360). Dmytro Javornyckyj led extensive scientific and educational activities. In his report on 1923, Dmytro Javornyckyj mentioned that cultural and educational museum activities aimed to be of scientifically demonstrational, anti-religious and politically educational character. For those entire he, as a museum head, used excursion lectures method. Museum attracted local youth to take part in the fieldwork, including students of Katerynoslav Institute for Public Education, students of worker's faculties, labor schools pupils, and also teaching and lecturing personnel, "people of manufactures" who spent their vacations in recreation centers (CDAVO: f. 166, inv. 4, f. 267, p. 6). A head of Berdyčiv Social-Historical Museum Todos Movčanivskyj, within the inspection and instructive institution activities, prepared scientific and popular lectures; he also prepared a report speech "Archaeology of Berdyčiv area and archaeological excavations in 1926". During the second quarter of 1926/1927 in Berdyčiv Museum there were given: 57 guided tours, 12 lectures and 97 explanatory talks (CDAVO: f. 166, inv. 6, f. 1722, p. 46-47). Oleksandr Fedorovskyj, a head of Harkiv Archaeology Museum, during Izium archaeological expedition in 1923, gave a number of lectures, including the one on a theme "Research results of Izium expedition" (CDAVO: f. 166, inv. 2, f. 469, p. 62-65). Viktor Goškevyč, a director of Herson History and Archaeology Museum, gave a course on "History of human cultures change in Hersonregion" for students of Herson Institute for Public Education; 
he prepared scientific and popular textbooks for labor schools pupils and lectures for village halls (CDAVO: f. 166, inv. 2, f. 1211, p. 42). Prominent excursion and lecture activities were led by Odessa History and Archaeology Museum fellows and post-graduates. During 1926 four guided tours a day were conducted; moreover, doctoral student Varvara Pora-Leonovyč led guided tours for the majority of groups which arrived to visit Olbia (CDAVO: f. 166, inv. 6, f. 6126, p. 17). Mykolaiv History and Archaeology Museum fellows prepared "Bugo-Lymanskyj" excursion tour which included: Mykolaiv - Bogojavlenske - Trojicke - Kisliakivka - Jefymivka - Oleksandrivka - Očakiv - Olbia - Parutine - Mykolaiv. The tour covered a number of history and archaeology sites, which were investigated with museum fellows' participation. Mykolaiv museum fellows' off-museum cultural and educational activities also involved giving lectures "for culture centers of those villages where investigations had been conducted" (Korotke zvidomlennia... 1928: 8). A popular form of cultural and educational activities was giving lectures-excursions at the excavation sites, for example, close to Stina village or Raikovecke defended settlement (fig. 11; fig. 12). Shooting documentaries had also been conducted during archaeological excavations.

Archival sources also give evidence that students and pupils were engaged to participating in museum archaeological fieldworks, among them were those who studied in Gluhiv, Zinovievsk, Lohvycia, Luhansk, Nikopol, Poltava, Romny. Mentioned practice developed youth's respect to local heritage objects. For example, Mykola Sibilov wrote in the first issue of Starovynnosti Iziumŝny (The Antiquities of Iziumŝyna):

[...] village kids-shepherds continually help me during the period of wide-scale material gathering, many of them - for several years in a row. Some of them grew up, turned into men and remained to be non-indifferent to the heritage sites... (Sibilov 1926b: 2).

Another way of archaeological knowledge popularization was represented in the form of public sessions inside UkrSSR museum institutions. Reports by Valerija Kozlovska "Archaeological Department of History Museum" and by Sylvestr Magura "Everyday tools of Trypillia culture settlements" were presented at the public sessions of All-Ukrainian Taras Ševčenko History Museum (CDAVO: f. 166, inv. 6, f. 3426, p. 5). Kamianets-Podilsky Scientific Society of VUAN sessions took place twice a month in Kamenec-Podilskyj Museum; Juhym Sicinskyj, a museum fellow, presented reports, for example Archaeological surveying in Kamenec region, etc. (Institute...). 
UkrSSR museum institutions of republican subordination during the 1920 s - first half of 1930s simultaneously were the powerful centers for qualified personnel training in history and archaeology. The training was conducted within the doctoral studies/postgraduate course (aspirantura) and seminars. Doctoral studies were officially introduced for museums in 1925; it was a form of training for research and pedagogical personnel. Future researchers and high school lecturers were prepared on a base of differently specialized UkrSSR research museums which had highly qualified fellows, multivolume specialized libraries and numerous practical materials for research. Archaeologists' training was conducted within Odessa History and Archaeology Museum, Harkiv Archaeology Museum and All-Ukrainian Taras Ševčenko History Museum.

Particularly, Emanuil Oksman, Varvara Pora-Leonovyč, Valentyna Veniaminova, Herbord Šteinwand, Mykola Virkau, Fedir Kozubovskyj, Musii Sinicyn, Jevgen Belen-de-Ballu got vocational preparation at Odessa History and Archaeology Museum doctoral studies during the 1920s - early 1930s. Seminars were another form of efficient professional training for research personnel in the field of history and archaeology; seminars were organized in Harkiv Archaeology Museum and All-Ukrainian Taras Ševčenko History Museum in Kyiv (Yanenko, Tarnavska 2011; Yanenko 2015).

Thereafter, UkrSSR museums during the 1920s - early 1930s were the powerful research centers for archaeological studies. Museum fellows led dynamic expeditionary activities, worked at methodology questions of archaeological fieldwork investigations, of artifacts processing and museumification, of archaeological technology, realized restoration activities. Research and scientific activities were represented within periodicals and museum institutions proceedings, expositional activities, cultural and educational activities (exhibitions, lectures, and public meetings). Students and pupils of various educational institutions were engaged to take part in museum fieldwork research. A number of museums were a background for qualified personnel preparation in history and archaeology. Analysis of museum institutions background and experience gained in the 1920s - early 1930s is important for the meaningful functioning of contemporary museums as modern research, scientific and educational centers. The experience of previous generations of museum archaeologists can be successfully used for further research and educational popularization based on scientific archaeological investigations.

dr Anna Yanienko

Państwowy Kijowsko - Peczerski

Historyczny i Kulturowy Rezerwat anna.pudovkina@gmail.com 


\section{BIBLIOGRAPHY}

Sources

Institute..., Institute of the Manuscript of V. I. Vernadsky National Library of Ukraine, fund X, file 18954.

SA IA NASU - Scientific Archives of the Institute of Archaeology of National Academy of Sciences of Ukraine:

fund I (Fedir Vovk's collection), file 456.

fund 3 , file 44 .

fund 3 (Sergij Gamčenko's collection), file 90.

fund VUAK (All-Ukrainian Archaeological Committee), file 46/11.

fund VUAK, file 50.

fund VUAK, file 60.

fund VUAK, file 85.

fund VUAK, file $86 / 2$ r.

fund VUAK, file 202/1.

fund VUAK, file 202/6.

fund VUAK, file 256.

fund VUAK, file 275.

fund VUAK, file 309/6.

fund VUAK, file 407.

fund VUAK, file 486.

CDAVO...CDAVO of Ukraine - Central State Archives of Supreme Bodies of Power and Government of Ukraine:

fund 166, inventory 2 , file 454 .

fund 166, inventory 2, file 469 .

fund 166, inventory 2, file 1211 .

fund 166, inventory 3 , file 427 .

fund 166 , inventory 3 , file 1166 .

fund 166, inventory 4, file 113 .

fund 166, inventory 4, file 267.

fund 166 , inventory 5 , file 262 .

fund 166 , inventory 5 , file 750 .

fund 166, inventory 6 , file 172 .

fund 166 , inventory 6 , file 1722 . 
fund 166 , inventory 6 , file 1861 .

fund 166 , inventory 6 , file 3426 .

fund 166 , inventory 6 , file 6115 .

fund 166 , inventory 6 , file 6126

fund 166 , inventory 6 , file 8199 .

fund 166 , inventory 6 , file 8919 .

fund 166 , inventory 6 , file 9425 .

Literature

Dubrovskyj V. V. (2007), Čerhovi zavdannia sučasnoho muzeinoho budivnyctva na Ukraini, "Ukrainskyj muzej”, zb. 1, repryntne perevydannia 1927 roku, Kyiv, s. 17-22.

Fedorovskyj A. S. (1921), Doistoričeskije drevnosti v basseine r. Donca, "Izvestija Lysyčanskoho muzeja", t. 1, vyp. 4, s. 35-44.

Fedorovskyj O. (1927), Instrukcii ta prohramy dla rozvidok I rejestracii pam'jatok archeologičnyh, Harkiv

Gamčenko S. S. (1925), Archeologični peršodžereła, sposoby ïh rejestracii ta zasoby ohorony: (Korotkyj vyklad), Zhytomyr.

Iziumŝyna... (1930), Iziumŝyna. Krajeznavčyj zbirnyk, Izium.

Kataloh... (1928), Kataloh vystavky dosiahnen miscevoi archeolohii za 10 rokiv (19171927) ta vystavky kartyn krajeznavčoho zmistu (krajevydy, typy, pam'jatnyky starovyny), Odesa.

Korotke zvidomlennia... (1928), Korotke zvidomlennia pro dijalnist Mykolaivskoho istoryko-archeolohičnoho muzeju za 1927 rik, Mykolaiv.

Litopys... (1927), Litopys muzeju. Červoni roky 1917-27, vyp. 8, Kherson.

Litopys... (1929), Litopys тиzеju. 1927-28, vyp. 9, Kherson.

Masalova I. I. (2008), Kyivski muzei v 1902-1928 rokah (za materialamy putivnykiv ta dovidnykiv po Kyjevu), "Lavrskyj almanah", vyp. 22, s. 132-149.

Nestula S. I. (1997), Archeolohičnyj Komitet Vseukrainskoi akademii nauk: etapy stanovlennia, Poltava.

Nikolajevŝyna... (1926), Nikolajevŝyna. Krajevedčeskyj sbornik, pod. red. V. M. Fidrovskoho i A. V. Kokoreva, Nikolaev.

Rudynskyj M. Ja. (2002/2003), Centr i peryferii v spravi muzeinij, publ. i kom. Mokliaka V. O., Nestuli O. O., "Archeolohichnyj litopys Livoberežnoi Ukrainy", nr 2/1, s. 27-29.

Rudynskyj M. Ja. (1925), Rozšuky po piskovyh nadberežžah ričok, "Biuleten Kabinetu Antropolohii ta Etnolohii im. Hv. Vovka", nr 1, s. 41-45.

Sibilov M. V. (Sibilov N. V.) (1926a), Starovynnosti Iziumŝyny: Albom maliunkiv, vyp. I, Izium. 
Sibilov M. V. (Sibilov N. V.) (1926b), Starovynnosti Iziumŝyny. (Archeolohični rozvidky v baseini Dincia v 1920-26 rr.), vyp. II, Izium.

Sibilov M. V. (Sibilov N. V.) (1928), Kak ja provožu archeologičeskije razvedki, "Krajevedenije", nr 5, s. 288-293.

Sibilov M. V. (Sibilov N. V.) (1930), Starovynnosti Iziumŝyny, vyp. IV, Izium.

Sibilov M. V. (Sibilov N. V.) (1935), Archeologičeskije razvedki v rajone novostrojek, "Sovetskaja etnohrafija", nr 3, s. 108-115.

Sibilov M. V. (Sibilov N. V.) (1936a), Archeologičeskije issledovanija krajevedčeskih muzejev, "Sovetskyj muzej", nr 3, s. 33-37.

Sibilov M. V. (Sibilov N. V.) (1936b), Zdanije i ekspozitcija krajevedčeskoho muzeija, "Sovetskyj muzej", nr 6, s. 15-16.

Starovynnosti...(1928), Starovynnosti Iziumŝyny, vyp. III, Izium.

V. K. (1930), Vystavka archeolohičnyh znahidok Doneckoho horodyŝa, "Hronika archeolohii ta mystectva", č. 2, s. 80.

Vidčyt... (1927), Vidčyt pro dijalnist Odeskoho deržavnoho istoryčno-archeolohičnoho muzeju za 1926 rik, Odesa.

Vidčyt... (1929), Vidčyt pro dijalnist Odeskoho deržavnoho istoryčno-archeolohičnoho muzeju za r.r. 1927 ta 1928, Odesa.

Yanenko A. S. (2015), Pidhotovka muzejnyh pracivnykiv v aspiranturi Vseukrainskoho istoryčnoho muzeju im. T. G. Ševčenka u druhij polovyni 1920-h-na pochatku 1930-h rr., "Siverŝyna v istorii Ukrainy”, vyp. 8, s. 286-299.

Yanenko A. S., Tarnavska S. V. (2011), Pidhotovka ta pidvyŝennia kvalifikacii archeolohičnyh kadriv pry muzejah USRR (1920-ti-počatok 1930-h rokiv), “ Siverŝyna v istorii Ukrainy", vyp. 5, s. 363-367.

Zbirnyk... (1928a) Zbirnyk, Volynskyj Naukovo-Doslidčyj Muzej, t. I, Žytomyr.

Zbirnyk... (1928b), Zbirnyk, Poltavskyj Deržavnyj Muzej im. V. Korolenka, t. I, Poltava.

Zbirnyk... (1929), Zbirnyk, Dnipropetrovskyj Krajevyj Istoryčno-Archeolohičnyj Muzej, t. I, Dnipropetrovske. 


\section{STRESZCZENIE}

\section{MUZEA JAKO BADAWCZE I NAUKOWE OŚRODKI STUDIÓW ARCHEOLOGICZNYCH (DOŚWIADCZENIA MUZEÓW UKRAIŃSKIEJ SOCJALISTYCZNEJ REPUBLIKI RADZIECKIEJ OD 1920 R. DO POŁOWY LAT TRZYDZIESTYCH XX W.)}

Muzea Ukraińskiej Socjalistycznej Republiki Radzieckej w okresie od lat 20. do połowy lat 30. XX wieku były silnymi ośrodkami badań archeologicznych. W działalność naukową na polu archeologii zaangażowanych było wówczas 56 instytucji muzealnych oraz ponad 100 archeologów - pracowników muzeów. Ze względu na brak wsparcia finansowego oraz odpowiednich kwalifikacji archeologów - muzealników, wiodącą formą badań archeologicznych były poszukiwania stanowisk archeologicznych (przeprowadzone w omawianym okresie badania powierzchniowe ujawniły 2000 stanowisk archeologicznych datowanych od paleolitu do późnego średniowiecza/współczesności). Ponadto muzealnicy opracowywali mapy archeologiczne różnych regionów USRR, rozwijali metody badacze i konserwacyjne, popularyzowali lokalną historię. Szukając dialogu naukowego, tworzyli przestrzeń komunikacyjną w celach badawczych, czyli stowarzyszenia naukowe.

Wyniki badań archeologicznych prezentowane były w publikacjach naukowych i popularnonaukowych (w sumie 150 publikacji), w trakcie lekcji muzealnych oraz wycieczek terenowych. Materiał archeologiczny, uzyskany podczas badań powierzchniowych, po odpowiednim przetworzeniu naukowym i technicznym, prezentowano na wystawach. W badaniach archeologicznych, obok pracowników muzealnych, brali udział studenci archeologii oraz osoby, zainteresowane lokalną historią. Centrami kształcenia młodych archeologów były zwłaszcza: Wszechukraińskie Muzeum Historii im. Tarasa Szewczenki w Kijowie, Historyczne i Archeologiczne Muzeum w Odessie oraz Historyczne i Archeologiczne Muzeum w Charkowie. Analiza doświadczenia uzyskanego przez instytucje muzealne w okresie od lat 20. do połowy lat 30 . XX wieku jest niezbędna dla właściwego funkcjonowania nowoczesnych muzeów jako ośrodków naukowych i edukacyjnych. 


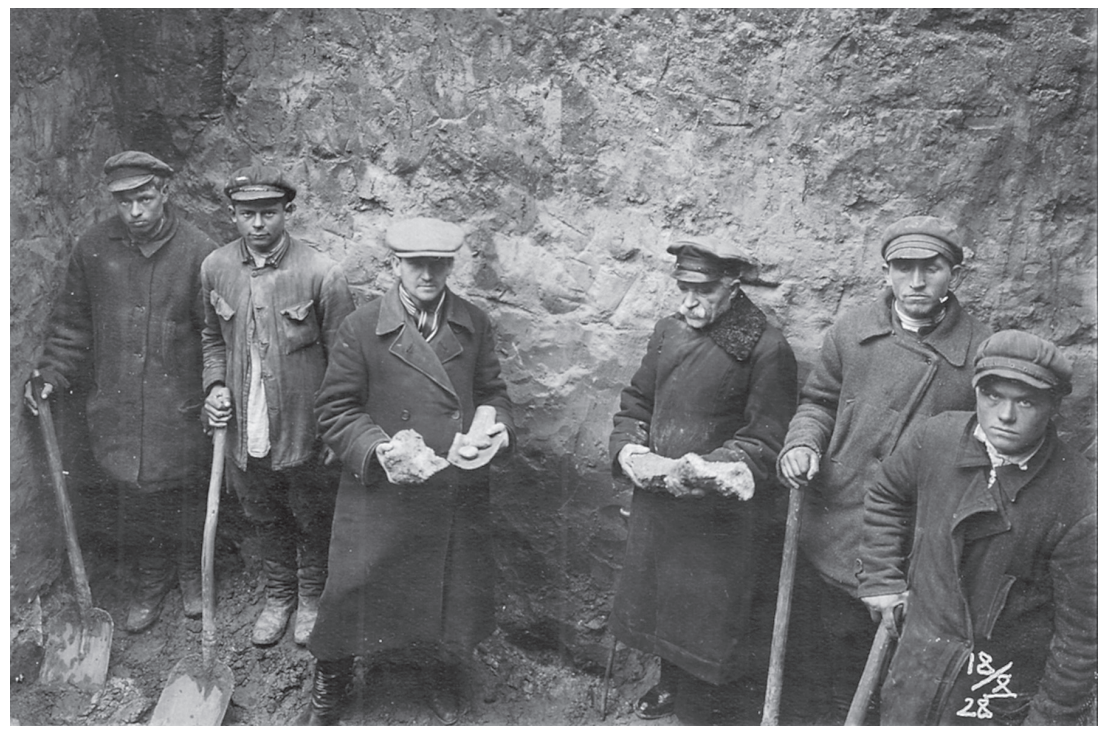

Fig. 1. Archaeological excavations of Paleolithic site in Oleksandriia arboretum (Bila Tserkva town) conducted by F. Ivanov and Y. Maslun, 1928

(Source: SA IA NASU: f. 30)

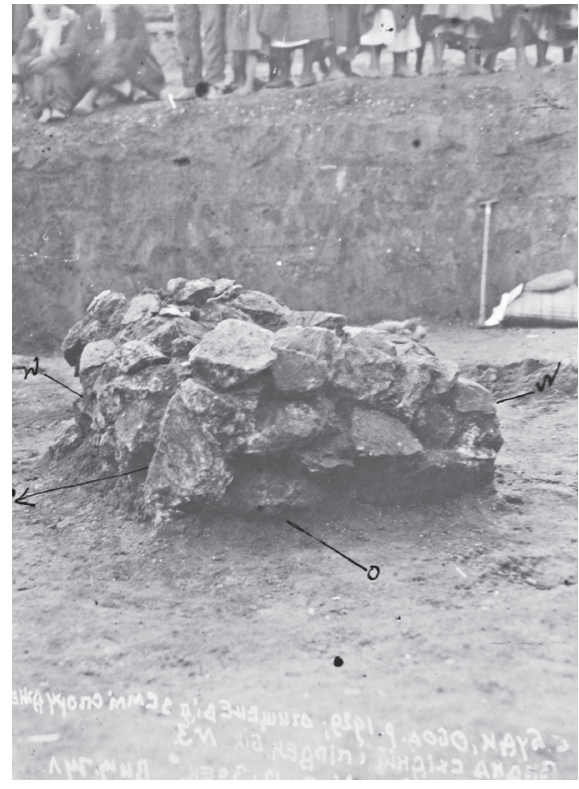

Fig. 2. Rescue archaeological excavations while stone-block pavement was done over the street in Budy village, 1929

(Source: SA IA NASU: f. 3)

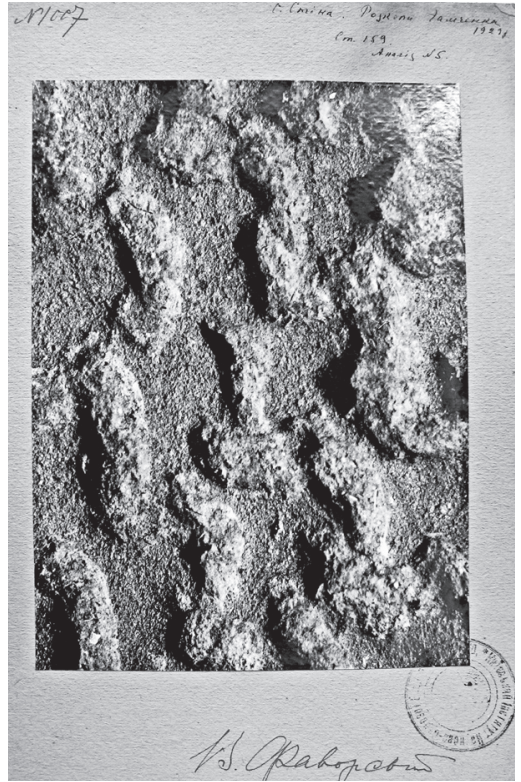

Fig. 3. A macrograph of ceramics fragment from excavations in Stina village signed by head of the Kyiv office (Institute) of scientific and forensic examination Vasyl Favorskyi, the 1920s (Source: SA IA NASU: f. 3) 


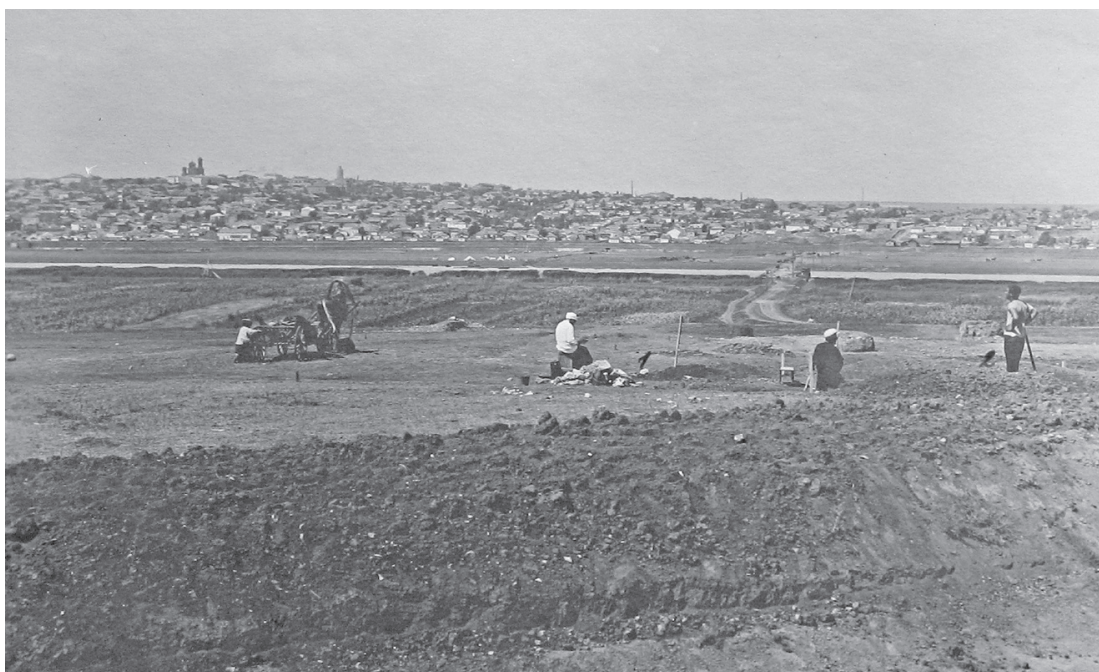

Fig. 4. The general view (from east) of Neolithic burial ground near Mariupol, 1930 (Source: SA IA NASU: f. VUAK)

ОДЕСЬКИЙ

ДЕРЖАВНИЙ ІСТОРИЧНО -АРХЕОЛОГІЧНИЙ МУЗЕЙ

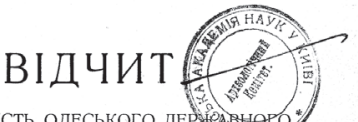

ПРО ДІЯЛЬНІСТЬ ОДЕСЬКОГО ДЕРХААЛНОНО IСТОРИЧНО - АРХЕОЛОГІЧНОГО МУЗЕН

3A P.P. 1927 TA 1928

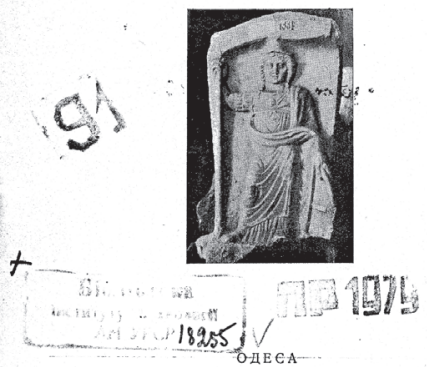

ВИДАННЯ ОДЕСБКОГО ДЕРЖАВНОГО ІСТ.-АРХ. МУЗЕЮ

1929

Fig. 5. Cover page of

Report on Odesa State Historical and Archaeological Museum activity in 1927 and 1928, 1929

(Source: SA IA NASU) $\frac{1}{1-646}$

ХЕРСОНСЬКИЙ ІСТОРИКО-АРХЕОЛОГІЧНИЙ МУЗЕЙ

випуск 8

\section{ЛІТОПИС МУЗЕЮ}

ЧЕРВОНІ РОКИ 1917—27

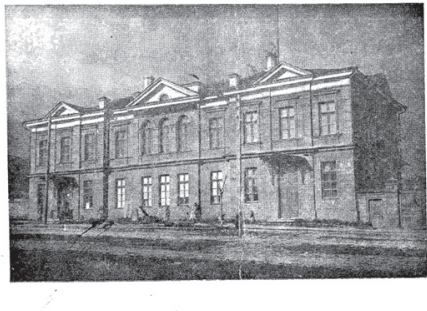

ХЕPCOH

1927

Fig. 6. Cover page of Kherson Historical and Archaeological Museum journal "Museum annals. Red years 1917-27", 1927 (Source: SA IA NASU) 


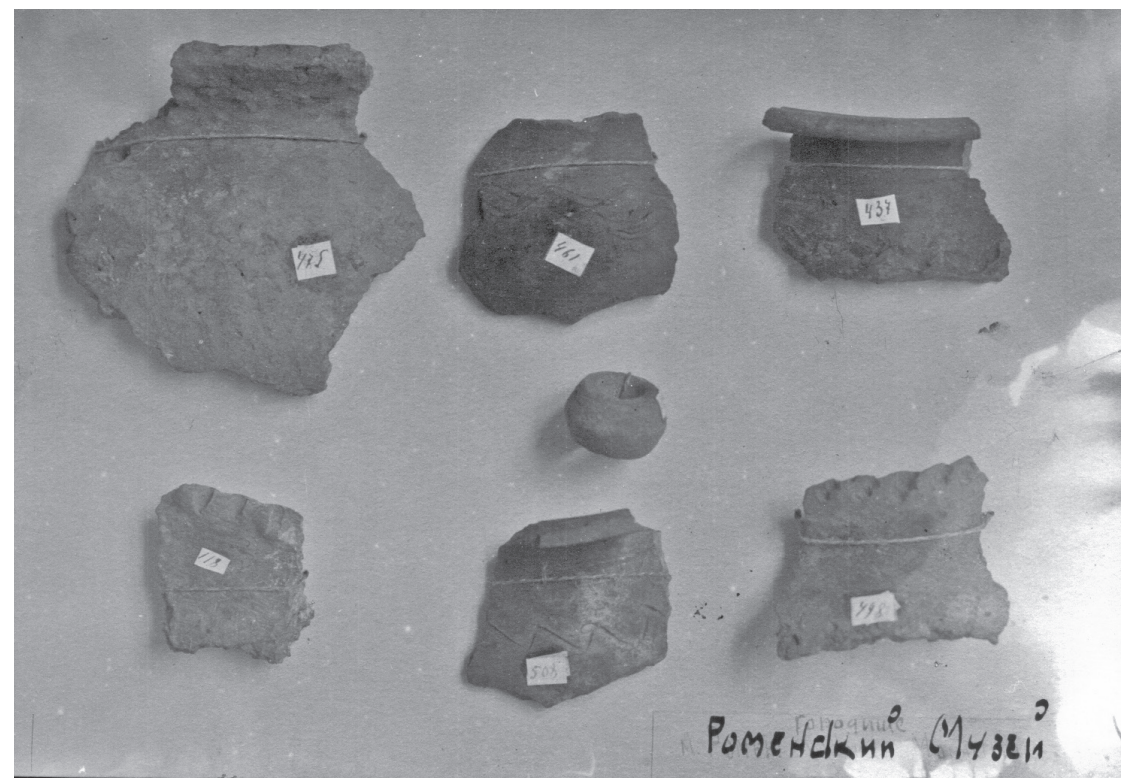

Fig. 7. A photo of tables with archaeological materials from Romny museum display (Source: SA IA NASU: f. VUAK)

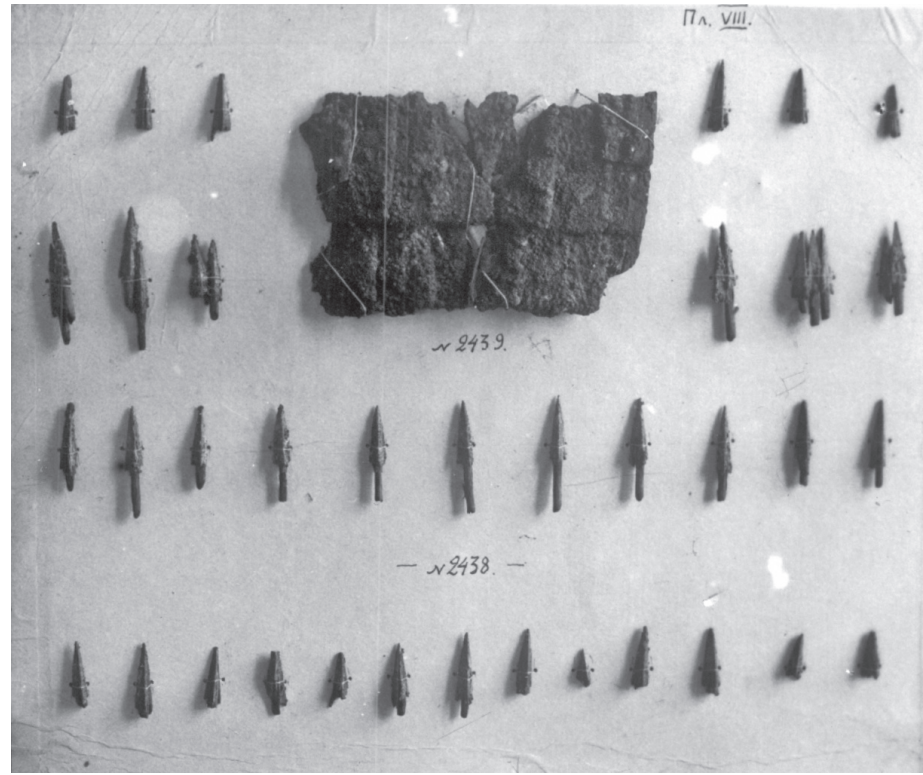

Fig. 8. A photo of tables with archaeological materials in Lubny museum display (Source: SA IA NASU: f. VUAK) 


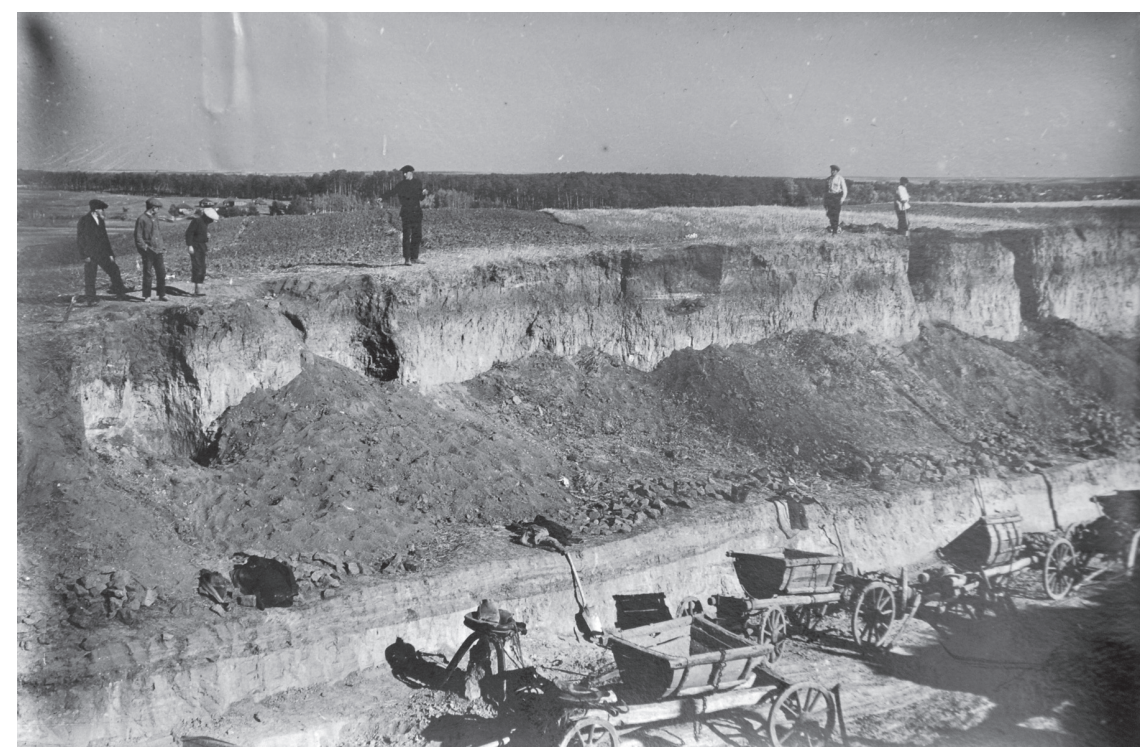

Fig. 9. Archaeological expedition of Scientific Institutions Administration of People's Commissariat of Education in Ukrainian SSR for research of Donetske settlement under the direction of Oleksandr Fedorovskyi, 1929 (Source: SA IA NASU: f. 19)

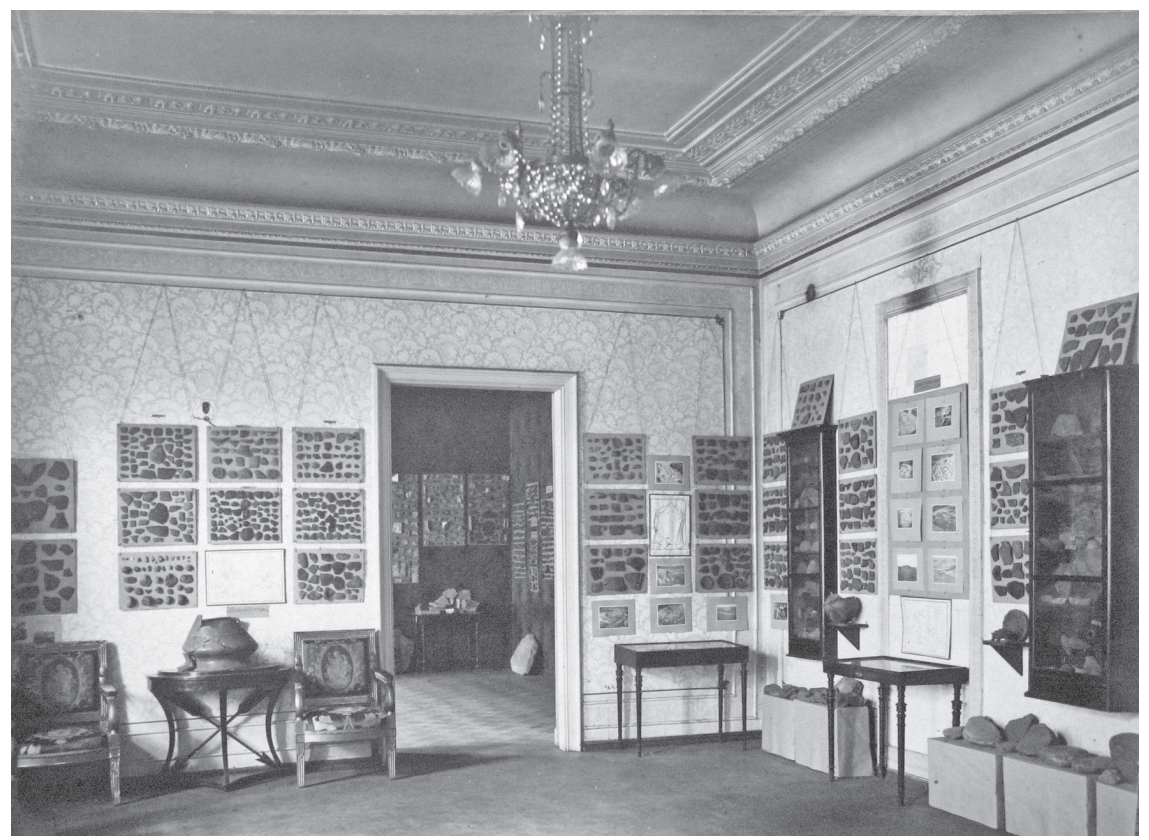

Fig. 10. General view of a report exhibit of All-Ukrainian Archaeological Committee over 1925 (Source: Institute...: f. 278, file 982) 


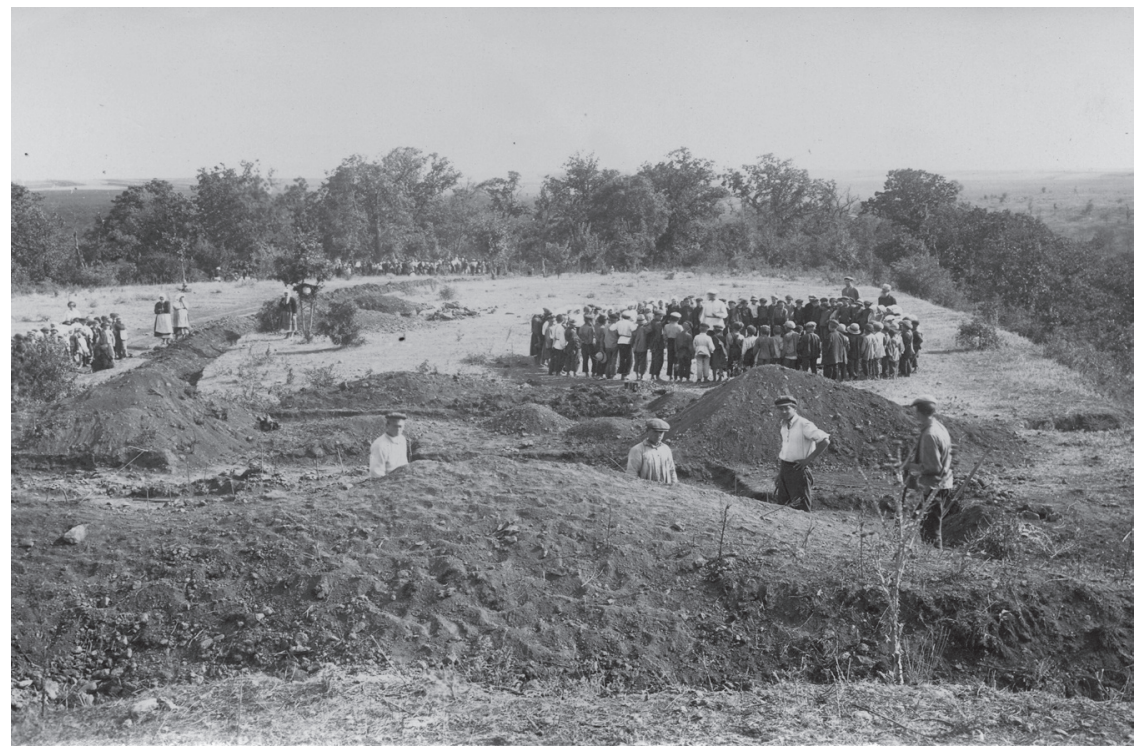

Fig. 11. Excursion-lecture at the archaeological excavation near Stina village (Source: SA IA NASU: f. 3)

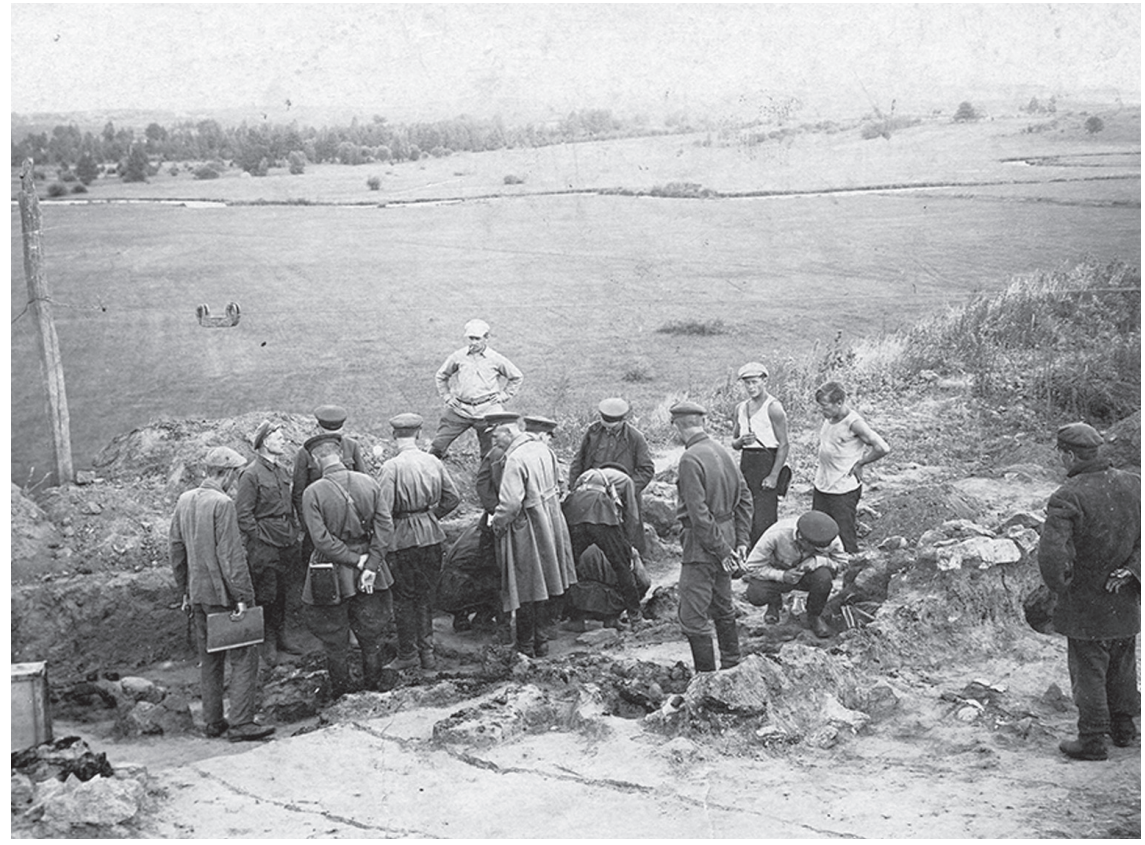

Fig. 12. Excursion-lecture at the archaeological excavation of Raikovetske settlement

(Source: Institute...: f. 243) 